Meta

Journal des tradlucteurs

Translators' Journal

\title{
To the Memory of Daniel Simeoni
}

\section{Hélène Buzelin et Deborah Folaron}

Volume 52, numéro 4, décembre 2007

La traduction et les études de réseaux

Translation and Network Studies

URI : https://id.erudit.org/iderudit/017688ar

DOI : https://doi.org/10.7202/017688ar

Aller au sommaire du numéro

Éditeur(s)

Les Presses de l'Université de Montréal

ISSN

0026-0452 (imprimé)

1492-1421 (numérique)

Découvrir la revue

Citer ce document

Buzelin, H. \& Folaron, D. (2007). To the Memory of Daniel Simeoni. Meta, 52(4),

603-604. https://doi.org/10.7202/017688ar

Ce document est protégé par la loi sur le droit d'auteur. L'utilisation des services d'Érudit (y compris la reproduction) est assujettie à sa politique d'utilisation que vous pouvez consulter en ligne.

https://apropos.erudit.org/fr/usagers/politique-dutilisation/ 
To Daniel Simeoni, for everything he gave to us, and to translation studies

Born in France in 1948, Daniel Simeoni specialized in linguistics at Université Paris VII before obtaining his doctorate degree from the École des Hautes Études en Sciences Sociales. Endowed with this double heritage and inspired by Elias as well as Bourdieu, he developed a way of theorizing translation practices at the crossroads of reflective sociology and phenomenological linguistics. In doing so, he tried to bridge the widening gap between the linguistic origins of translation studies and the "cultural turn" it had embraced in the 1980s. Convinced of the power of Bourdieu's concepts, he nonetheless recognized the need to revisit them, putting into focus a subject essential to the analysis of social interaction, but to which he felt Bourdieu understood very little: language and translation.

Daniel Simeoni defended a humanist vision of translation and the interdisciplinarity of translation studies, wary all along of facile links and quick conclusions. His texts revisit the concept of translation norm and explain the formation of the translator's habitus through history. They question what constitutes a good case study or appropriate contextualization. They unveil the reasons why translation, a practice so profoundly constitutive of social life, had always failed to be regarded as a legitimate sociological object, a fact that only changed very recently. His constant reflexivity and concern for the construction of memory also led him to interrogate what future generations of translation scholars would retain from the thirty years of research leading to the institutionalization of their discipline. Not only did Daniel Simeoni take the risk of addressing the most difficult, profound and unsettling questions about the very foundations of our field, the nature of its object and our commitment as researchers, he succeeded in doing so with subtlety, wit, humility (even while tremendously erudite) and, above all, with impeccable intellectual wisdom, rigor and integrity. Though always faithful to his convictions, he never indulged in polemical discourses, except when it came to censorship, a practice that revolted him immensely and which he denounced unhesitatingly, even at the risk of being ostracized. Thanks to him, translation studies scholars found - and will continue to find - responses to their questions, and multiple avenues of inquiry for research.

These writings were in the image of their author, for Daniel Simeoni was an immeasurably generous man. At Glendon College of York University, where he had been a professor for nine years, he gave all he could. He came in early, left late, and if you were to find yourself at the bus stop with him, the ride from campus to downtown Toronto, otherwise interminable, passed in the blink of an eye. He would speak of the latest essay he'd read, an article that had intrigued him, the boxes of books he hadn't yet unpacked, tell you about his interest for film editing, where to find repertory films in Toronto, the best markets, good restaurants, or the history of migration 
in his lively neighbourhood. His zeal for life and his curiosity knew no bounds. When he finally took a holiday, he was the kind of person who would observe unusual stones on the seaside and bring them all back home. "The perfection of nature always reminds me of the imperfection of our own work," he would later comment, while gently poking fun at himself for having carried back all those heavy rocks in his suitcase.

Since 2002 he carried out a historiographical project on Domenico Valentini, author of the first complete translation of Shakespeare's Julius Caesar in Italy (1756). He had followed the trail of his author to Sienna, and for a year combed libraries, scrutinized boxes of archival materials, and consulted with experts. In searching for clues, he had finally discovered unexpected links between the fate of his writer and the political plots in Italy at the time. "It's an unbelievable story, I wonder if I shouldn't write a detective novel instead," he said one day. Though projected with humour, the thought stemmed from a profound question on the ties between biography, fiction and essay, on how to best formulate ideas and to write (hi)stories in a way that they could eventually make a difference. If you asked him to which publisher he planned to submit the manuscript, he would ponder. "Well, it depends on which language I decide to write in: French, English, or why not Italian?” The son of two emigrants of distinct linguistic backgrounds, he was sensitive to linguistic diversity and knew only too well how the choice of a language, like that of the tiniest word, was a crucial one. I don't know what language he finally opted for, or if he had time to complete the book. More concerned about the future of his students than his career, he devoted the past two years supporting and leading the Master's program at Glendon. He was developing a doctoral program as well.

On the weekend of November 3rd, 2007, he suddenly departed in the cruelest way, leaving behind all the projects he never had a chance to complete. With his death, translation studies lost one of its greatest thinkers, a most inspiring author and noblehearted man who, despite his quiet modesty, left an indelible print on those who had the privilege of crossing the much too short path of his life. We dedicate this special issue to his memory, and to him, without whom its very idea and birth would not have come to pass.

Hélène Buzelin and Deborah Folaron 